\title{
The Vagaries of the In-Between: Labor Citizenship in the Persian Gulf
}

\author{
Zahra R. Babar
}

Associate Director of Research, Center for International and Regional Studies, Georgetown University-Qatar

Corresponding author. Email: zahra.babar@georgetown.edu

\section{Dhobi ka kuta, Na ghar ka na ghaat $k a^{1}$}

The washer-man's dog belongs neither to the home nor to the river bank.

There is no precise English equivalent to this Hindustani proverb. ${ }^{2}$ A rolling stone gathers no moss, between the devil and the deep blue sea, between a rock and a hard place, torn between two masters -none of these really fit. The dhobi ka kuta is the dog who figuratively and literally runs every day between two places, two obligations, and two choices. Does he stay behind to guard the master's house or does he guard his master as he washes clothes by the river? There will be a trade-off either way. The phrase does not conjure up vagabond restlessness or nomadic liberation. It evokes the anxiety of rootlessness, and the lack of certainty about choice and loyalty. It is about the doubt cast your way for not picking one thing over the other. It is about being stuck in the vagaries of the in-between.

Migrants' lives, at the existential level, reflect the dilemma of the dhobi's kuta. Temporary labor migrants in the Persian Gulf are perpetually tied to obligations to those they have left behind as well as duties to those they live among in the moment. Really belonging neither at home nor to their currently adopted land, they are occupants of a liminal space where they are without political status, without political weight, without political solidarities, and without political rights. For the duration of their time overseas, and for some this might mean decades, they have a limited claim to any of those things in their country of nationality as well.

Narratives of Gulf labor migrants frequently veer between two poles. From one perspective they are seen as voluntary economic actors, animated only in principle by their material goals. Momentary contributors to economies that need their labor, they lack demonstrable loyalty to their nation-states and have little longterm connection to the countries that host them. From this position, temporary labor migrants might at most be considered an interest group unto themselves, whose collective goals are merely better pay and improved employment conditions. The flip side of this is the view of migrants as voiceless, deprived of any agency, vulnerable, and in need of others to advocate on their behalf. Casting migrants solely as victims, this pole also diminishes their capacity, value, positionality, and engagement in the Gulf. Both of these views elide the nuances of migrants' subjective experiences and autonomy and divert our attention from their multiple practices and forms of resistance to power and oppression.

In the era of globalization with its insatiable hunger for cheaper sources of labor, migrant workers regularly contend with situations of exploitation and abysmal labor rights violations. However, migrants' experiences as well as their responses are a product of dysfunctionalities in our global political and economic systems and the structural inequalities they produce. If labor migrants are a sidelined community, for political scientists they are frequently a marginalized subject. Abandoned as a problematic category by political ideologies of the left and right, lacking broader goals or mechanisms of cooperation with other social classes or social interests, and seldom incorporated into the study of social movements, they have been overlooked by those who study political phenomena in the Persian Gulf.

\footnotetext{
${ }^{1}$ This saying was narrated to me by a Pakistani return migrant in a conversation I had with him in 2017 about his years living and working in the UAE.

${ }^{2}$ Hindi-Urdu, the lingua franca of northern India and Pakistan.

( The Author(s), 2020. Published by Cambridge University Press. This is an Open Access article, distributed under the terms of the Creative Commons Attribution licence (http://creativecommons.org/licenses/by/4.0/), which permits unrestricted re-use, distribution, and reproduction in any medium, provided the original work is properly cited.
} 
Migrants provide a critical lens through which to think about changing dynamics around borders and boundaries, statehood and sovereignty, inclusion, participation, identity, belonging, status, nationality, and citizenship. Migrants through their exclusions serve to reinforce national identities, cohesion, and even the value of citizenship. In the Persian Gulf, temporary labor migrants provide a visible and stark contrast to Gulf national identity. They hold up the mirror that reflects, magnifies, and consolidates Gulf citizenship into a visible, meaningful thing. In these six monarchies, citizenship status brings access to expanded socioeconomic rights that are denied to migrants, thus masking (for those who buy into the false binary) the extreme deprivation of political as well as labor rights for citizens and noncitizens alike. Current forms of migrant worker activism have existed for decades in the Gulf, and these forms of engagement are implicitly and explicitly political, because labor and the way it is managed in the region is deeply political. All these complexities make this region an exceptional arena for exploration of the contradictions at the heart of contemporary citizenship and migration regimes.

\section{Protest and In/Visibility in The Gulf}

The Gulf States draw in millions of temporary workers for jobs that are either occupationally unappealing or too low paid to attract citizens. Although there is an obvious cost advantage to hiring foreign workers, for Gulf employers what makes temporary labor migrants even more desirable is the perception that they will be docile employees due to their tenuous status. Not just in the Gulf but in multiple global locations immigration policymakers and profit-oriented businesses would agree with this and are similarly embracing the idea of workforces made up of temporary labor migrants. Disposable and cheap, migrant workers are a preferred economic actor for many lower tiers of the global labor market-easily controlled and thoroughly disenfranchised.

Citizenship theory has moved well beyond the study of citizenship as a formal legal status to focus on what gives citizenship its actual meaning and substance, that is, the assignment of a host of rights and duties. For the most part labor rights have been cast in a nonessential basket and divorced from citizenship. In the Gulf, migrants' rights are aligned with a very limited and discrete exercise of labor rights tied to job contracts and national labor laws, which can be manipulated to favor employers. Given that labor rights are presented by Gulf States as a replacement for citizens' rights and that migrants' status is correlated with their labor participation, conceptually those who are engaging in labor activism protest are engaging in a specific display of contentious citizenship.

Ahmed Kanna, writing on migrant workers' labor strikes and protests in the United Arab Emirates (UAE), suggests that these forms of migrant activism are often ignored by both media and policymakers (both internationally and locally, but for different reasons). ${ }^{3}$ Migrants' acts of striking or engaging in protest against their living and working conditions are not viewed as engaging in "political" forms of public expression and instead are seen to be acts taking place within the sphere of private employer-employee relations. Supposedly the state is not the audience of appeal and stands at a safe and objective distance, or if involved it is only as neutral arbitrator, to ensure accountability of the employer toward his employees and vice versa. This depoliticization of migrant worker protests in the Gulf is strategic and deliberate; it is situated within the broader narrative of neoliberalism that also attempts to depoliticize workers' demands and make invisible their participation in political actions at a global level. As has been demonstrated in Bahrain and Oman, Gulf citizens who campaign for labor rights and trade unionists also hold a complicated view of migrants and how to incorporate them into labor activism. ${ }^{4}$ Citizen activists tend to see migrants as potential "scabs," whose apolitical status and willingness to endure substandard working conditions threatens the success of labor action for everyone.

Protests that broke out across the Arab world in 2011 were driven by sentiments of social and economic disenfranchisement. Income inequality, unemployment, and a corrupt and nonresponsive state were all triggers for mobilization across the region. Citizens on the street demanding economic justice

\footnotetext{
${ }^{3}$ Ahmed Kanna, “A Politics of Non-Recognition? Biopolitics of Arab Gulf Worker Protests in the Year of Uprisings," Interface 4, no. 1 (2012): 146-64.

${ }^{4}$ For more on this point see the Jadalyyia report "Migrant Workers and Labour Unions in the Gulf: An Interview with Karim Rahdi," 23 June 2014, https://www.jadaliyya.com/Details/30862.
} 
and job security were not self-interested workers; they were engaging in explicitly political actions against the authoritarian state. Although demonstrations by migrant workers in the Gulf may look different from the overtly political expressions of the uprisings in Egypt and Tunisia, they are in their own ways manifestations of the anger at being marginalized and ignored.

On 22 May 2020, in the midst of Qatar's Covid-19 lockdown, about a hundred male migrant workers assembled to protest against the nonpayment of wages by their employer. These workers gathered despite the fact that Qatar since 13 March had imposed strict Covid-19 social distancing regulations curtailing the mobility of citizens and residents. The workers protested in public despite knowing that doing so not only increased their chances of being infected by the virus but also would draw the attention and ire of the authorities. Limited information is available on how the crowd was dispersed and what happened to the protestors in the aftermath. However, a subsequent statement was released a few days later by Qatar's Ministry of Administration, Labor and Social Affairs. The press release acknowledged that an investigation had been carried out following the demonstration, and that legal actions had been initiated against the employer for nonpayment of wages. The ministry stated that the protesting workers were all paid the salaries due to them.

In April 2019 migrant construction workers on FIFA 2022 projects staged protests in relation to overdue wages and harsh work conditions. Local media outlets gave limited coverage to these protests. In August, information circulated on social media that about 800 (mainly Bangladeshi) workers employed by two large construction companies had gone on strike to protest poor working conditions and unpaid, delayed, or reduced wages. Although no public information was available on these strikes, social media suggested that they were taking place in Labor City as well as the Al Shahaniya municipality. On 17 August the Qatari Government Communication Office released a public statement confirming that a number of workers in $\mathrm{Al}$ Shahaniya had gone on strike in response to not having received their wages for over three months. The statement indicated that a rapid investigation had found that indeed workers' salaries had not been paid, and by 6 August all the workers were paid their owed salaries.

The 22 May choice of location for staging of the protest is of note. Migrant workers across the Gulf have for decades engaged in strike actions, but for the most part these actions have taken place on work sites, at industrial locations, or within labor camps, generally removed from the public eye and the view of the broader population. Additionally, there are patterns of individualized resistance by migrant workers that are even more invisible, as these occur outside the spectrum of organized collective action and joint work stoppages. Migrants in dispute with supervisors and employers, and frustrated by the lack of progress when seeking redress, have been known to resort to labor refusal tactics. When all else fails, migrants may choose to stay in their rooms and not go to work as a deliberate means by which to have their grievances addressed. These actions do carry inherent risk, as migrants refusing to work may face disciplinary actions, have their salaries docked for the days they do not work, or in worst case scenarios lose their jobs and be deported. But these individual actions also have produced positive outcomes for migrants, which is why they persist as a form of worker action. Employers have to negotiate with workers when there are critical projects that need their labor, as deportation and finding replacement workers is neither quick nor easy. In addition to the fact that they can lead to positive outcomes for migrants, there are spillover effects from these individualized forms of resistance. Successes gained remind others of the power of autonomous action and serve to inspire migrants to adopt similar tactics for negotiating with their employers on a variety of labor rights issues. These individual acts also may serve to generate new forms of labor solidarity among migrant communities, which can even transcend the deliberate structures of segregation and separation that are imposed on them. Migrants engaging in these personal acts of labor refusal are demonstrating forms of resistance, which for some leads to engaging in broader forms of collective labor activism. Migrants in the Gulf who participate in collective strikes and strategic work stoppages have often experienced their first taste of autonomy and the power of labor action when they stayed in their rooms and withdrew their participation.

The May protest in Doha was held in Msheireb, the "new old" downtown, one of the recent upmarket and luxurious real estate developments hoping to attract higher-income foreigners and citizens to its residential and business towers. This is a part of the city that has undergone a dramatic physical transformation in the past few years, billed as a "sustainable regeneration" project. Ten years ago this area was known for its Nepali restaurants doling out dumplings by the dozen, for its bustling Bengali sari 
shops, and for its Friday night crowds, when the congested streets would be teaming with an endless sea of primarily South Asian men.

Now reimagined, repurposed, and metamorphosed, seemingly overnight, the paved, wide, and, these days, largely empty streets are lined with rows of carefully planted and artfully arranged trees and large, pristine, and quite starkly beautiful buildings. Qatari migrant workers protesting in this space, miles away from their labor camps and cheek-by-jowl shared housing units, are intent on drawing attention to more than just their wage deprivations. Occupying this space, this particular place that stands above even Doha's other glamor spots, migrants remind the public of who put in the sweat and time to construct these buildings in the first place and who used to dominate these streets a decade ago. They challenge their daily and normalized spatial exclusions from such parts of the Gulf city, the parts where they are meant to be completely unseen, or at most wear a beige uniform that seamlessly blends into the background. Workers protesting in the Gulf s most privileged streets and neighborhoods are well aware of the parts of the city where they are meant to belong, and the parts where they are meant to be invisible. In the midst of Covid-19 closures and restrictions that have created deep financial pain and precarity and emphasized the differences between white-collar work and blue-collar work, these migrants' demonstrations serve as even more powerful tool. The protest in Msheireb certainly drew attention to labor exploitation, but it also highlighted the stark differences between those who can shelter in place and demonstrate their commitment to "safety and the public good," and those "essential workers" who do not have the luxury of working from home. During a strange moment when large swaths of wealthier foreigners and locals were suddenly absent from their offices and invisible in public spaces, blue-collar migrants demanded to be seen and heard.

Mshereib is an echo of other iconic locations chosen by migrants across the Gulf for staging public protests. Over the past eight years the collective activism of migrants is occurring in full public view rather than in out-of-sight industrial areas. In 2015, South Asian workers in Dubai protesting against real estate developer Emaar organized a sit-in on Sheikh Mohammed bin Rashid Boulevard, the busy restaurant-lined strip that circles downtown Dubai, bringing traffic to a stop. These workers protesting in these spaces, symbolically and practically off-limits to them, are reflecting what De Genova has earlier suggested, that: "migrant workers have asserted their autonomy and prerogative through insubordinate acts calling attention to the mere corporeal fact of their deportable presence." 5

Qatar and the UAE are by no means alone when it comes to greater public visibility of migrant worker protests since 2011. From thousands of garment factory workers demonstrating in Bahrain, to cleaners and airport porters refusing to go to work in Saudi Arabia, to health technicians' strikes in Kuwait, to multiple construction workers' protests in the UAE, the past few years have seen a surge of migrant labor activism across the region. Bahrain and Kuwait have witnessed an expansion of labor strikes and activism among both citizen workers and migrants, although seldom do these two groups strike collectively. Frequently the media depiction of these strikes portrays them as group demands for material improvement, primarily related to wages, but the reality is far more complex. Protests have been driven by late wage payments but also have been triggered by other demands, including the quality and quantity of food and access to health care, sick leave, and annual holidays. Workers have complained about not being allowed to take a break to have a drink of water or visit the bathroom. Protestors have spoken of unhappiness with how they are spoken to by their supervisors, and how they are generally treated. Some protests have occurred as migrant workers state that they resent being treated differently from each other based on their race or national affiliation. During strike actions and protests Gulf migrants have articulated that they are subjected to forms of class and ethnic marginalization. In a context in which mobilized labor action is criminalized and those who engage in it may face immediate deportation, migrants have risked a lot to protest against much more than delayed wages.

\section{Citizens of Where and What?}

The Gulf states appear to be showing a more sophisticated approach to quelling and managing labor activism and are more strategic in their communication on and around migrants' protests and strikes.

\footnotetext{
${ }^{5}$ Nicholas De Genova, "Conflicts of Mobility, and the Mobility of Conflict: Rightlessness, Presence, Subjectivity, Freedom," Subjectivity, no. 29 (2009): 445-66.
} 
Although patterns of extreme suppression of labor activism continue, there is increasing public messaging about states' attempts to "balance" the rights of employers and employees. Through a carefully crafted response the state wishes to position itself as an impartial mediator there to uphold the law, as demonstrated in Qatar's handling of strike actions in 2019 and 2020. The aftermath of some of the recent worker protests in the region have led to positive (although modest) outcomes, underlining the value that strikes and work stoppages have in improving the immediate conditions of the working class. However, despite this, Gulf employers continue to deny that the resolution of salary disputes are directly tied to workers' collective action. Gulf authorities' interventions, when they occur, do try to provide some justification for the employer's behavior, suggesting that the nonpayment of wages was out of the employer's control. In the recent case of the workers' protest in Doha in May 2020 the official statement from Qatari authorities diluted the disciplining of the offending company by stating that the company had been late in paying wages because of the financial difficulties it was facing in relation to Covid-19.

Migrant workers' protests do not always have a happy ending. The Gulf states count on the continued effectiveness of laws that ban participation in collective action or unionization and also make employees' "good behavior" a contingency for retaining the right to a job and visa. What is seldom discussed by the media or critics of the Gulf states' migration regime is the role of foreign companies in strike activities, and how the system allows them to engage in dominance over workers and suppression of their rights in a way that would not be possible in other contexts. Transnational companies profit from the lack of collective bargaining as well as the ease of canceling jobs and visas to nip problematic work forces in the bud. For example, G4S, a British multinational security services company that directly manages its operations in the UAE, came under scrutiny in July 2020 as 1,000 of its employees who said they had not received a salary for over five months had their job contracts terminated and visas canceled without any ability to return home.

Any signs of explicitly political activism by migrants continues to be ruthlessly suppressed via detention, revocation of a work permit, and deportation. Labor activism that is not explicitly political falls into more of a grey area, but certainly has produced severe consequences for many migrants over the past ten years if seen to potentially destabilize broader social and economic goals. At the most extreme end has been the deportation of strike leaders and application of unilateral punishments to entire workforces, even to those migrants who were not striking. Gulf employers argue that if you attempt to bargain collectively, be prepared to be fired collectively, and there are cases of even those employees not participating in a strike losing their jobs and being deported along with their striking friends.

There is another factor to consider that disciplines the activism of migrants: the lack of enthusiasm or support from their own states for their citizens who complain of work conditions or who engage in labor protest in the Gulf. Many states would like to maintain the flow of remittances at all costs and carefully nurture their relations with the Gulf states to ensure the status quo remains. Migrants who are detained after labor activism feel that they do not get support or assistance from their embassies. They also speak about the lack of intercession on their behalf by their home countries when they are in the midst of a dispute with their employers. Not only have migrant workers become commodified in the Gulf; they also are commodified by their own states. They are irrelevant as citizens, aside from their physical labor that sends foreign currency back home.

Forms of exclusion are not only nested within host nation-states. Inclusion and exclusion can cross borders, as people carry their forms of social stratification with them in terms of class, gender, race, and income. ${ }^{6}$ For lower-income male and female migrants from Asia and Africa this very much holds true. Their status and treatment in the Gulf result not only from their relationship to the Gulf, but also from where they are positioned in their home states. Gulf migrants might not be from the most deprived parts of their societies (the poorest do not have the ability to migrate), but certainly they are marginalized in their home countries by various class, caste, religious, ethno-national, and other markers. One of the drivers for migration is the unequal access to resources and power in migrants' home states.

A lack of ability to actualize their full citizenship rights in their home countries influences migrants' senses of self in the Gulf and colors their subjective interpretation of the migratory experience. In

\footnotetext{
${ }^{6}$ David Owen, "Migration, Structural Injustice and Domination on 'Race,' Mobility and Transnational Positional Difference," Journal of Ethnic and Migration Studies 46, no. 12 (2019): 2585-601, doi: 10.1080/1369183X.2018.1561067.
} 
interviews conducted with Pakistani return migrants from Saudi Arabia, I was struck by how deeply angry they were at the Pakistani state. For those with the worst Gulf experiences, their harshest criticism was reserved for their own home country. They said that Pakistani authorities had sent them off with drums and waving banners, but when they were exploited by Gulf employers and approached their embassies for support they got nothing at all. Many who chose to come and work in the Gulf expressed that they already knew they were on the fringes of their own societies. When facing trouble, they learned that their country of citizenship would not intervene to help but would leave them to manage on their own, stranded, unemployed, without wages to get back home and unable to pay for a return flight. Some spoke of turning to irregularity and criminality to survive, of the ordeals of time in Saudi prisons, and of holding Pakistan responsible for much of this. Migrant protests in the Gulf are implicitly directed at their own countries of origin, for their neglect at home and their ambivalence toward their offshore workers.

There is a long history of migrants' participation in leftist movements and other forms of political activism as well as labor engagement in the Arab states of the Persian Gulf. ${ }^{7}$ It was the very political threat of migrants as political subjects in the middle of the last century that caused the Gulf monarchies to develop new means of controlling labor migration into the region (not to mention British and American imperial efforts to curtail any development of indigenous labor consciousness). Although workers were clearly going to be needed to meet economic development goals, ensuring that these workers did not form cooperative forums for pressing for political and social change was essential. Systems to control and discipline workers, such as immigration levers, labor law, and even housing regulations, have been deployed toward this purpose. Legally, socially, and physically migrants have been segregated from host societies and divided among themselves. Explicit and implicit means have served to reinforce that labor migrants are culturally alien not only to Gulf citizens but also to each other-to diminish the potential political and social threat they could pose if unified.

Their citizenship status in this transnational realm is diffuse and fragmented, and their experiences of active citizenship are layered on top of and made fragile by their dhobi ka kutta realities. Migrants' public acts of expression in the Gulf are therefore aimed at multiple audiences: the host state that suppresses them, their own states that appear to have abandoned them, employers, labor brokers and private actors who have manipulated and exploited them, and the larger citizen and noncitizen communities that ignore them. All of these spectators are complicit in the systems and structures that oppress and alienate them.

\footnotetext{
${ }^{7}$ John Chalcraft, "Migration and Popular Protest in the Arabian Peninsula and the Gulf in the 1950s and1960s," International Labor and Working-Class History, no. 79 (2011): 28-47; John Chalcraft, "Labour Protest and Hegemony in Egypt and the Arabian Peninsula," in Social Movements in the Global South: Dispossession, Development and Resistance, ed. Sara C. Motta and Alf Gunvald Nilsen (New York: Palgrave Macmillan, 2011), 35-58.
}

Cite this article: Babar ZR (2020). The Vagaries of the In-Between: Labor Citizenship in the Persian Gulf. International Journal of Middle East Studies 52, 765-770. https://doi.org/10.1017/S0020743820001075 